University of Nebraska - Lincoln

DigitalCommons@University of Nebraska - Lincoln

Biochemistry -- Faculty Publications

Biochemistry, Department of

1984

THE ROLE OF RECOGNITION IN PLANT DISEASE

J. M. Daly

Follow this and additional works at: https://digitalcommons.unl.edu/biochemfacpub

Part of the Biochemistry Commons, Biotechnology Commons, and the Other Biochemistry, Biophysics, and Structural Biology Commons

This Article is brought to you for free and open access by the Biochemistry, Department of at DigitalCommons@University of Nebraska - Lincoln. It has been accepted for inclusion in Biochemistry -- Faculty Publications by an authorized administrator of DigitalCommons@University of Nebraska - Lincoln. 


\title{
THE ROLE OF RECOGNITION IN PLANT DISEASE ${ }^{1}$
}

\author{
J. M. Daly
}

Department of Agricultural Biochemistry, University of Nebraska, Lincoln, Nebraska 68583-0718

\section{INTRODUCTION}

As noted by Sequeira $(110,111)$, the term recognition has become very popular in the literature of host-pathogen interactions over the last ten years. Despite recent facile usage, its meaning is not always clear to me. Recognition is defined by Clarke \& Knox (16) as the "initial event in cell-cell communication that elicits a defined biochemical, physiological, or morphological response." This requires the not-so-easy task of defining "initial event" and "communication" with precise chemical or physical mechanisms. For pathologists, Sequeira (110) has provided a more restricted meaning: "An early specific event that triggers a rapid, overt response by the host, either facilitating or impeding further growth of the pathogen."

The word specific in this definition is the key to both the current popularity of the term and the recent appearance of models of host-pathogen interactions predicated on recognition phenomena. It is trite to repeat, but any chemical or physical theory of disease reaction (resistance or susceptibility) must account for the specificity of that reaction (19). In molecular terms, it also should be consistent with the mode of inheritance of the reaction (18). In recent years, the latter requirement has entailed, for many workers, allegiance with Flor's gene-for-gene concept (43), as further amplified by the considerations of Person (102), Day (27), Ellingboe (40, 41), and Sidhu (114). The genetic data, although complete for only a relative small number of plant diseases (19), is generally interpreted to mean that the product of a host resistance gene interacts

\footnotetext{
'Published with the approval of the director, Nebraska Agricultural Experiment Station, as paper number 7442, Joumal Series.
} 
biochemically with the product of an avirulence gene of the pathogen. The lack of either product, or both, results in susceptibility. In this view, the unique biochemical determinants of disease reaction are for resistance (incompatibility) $(13,38,40,41)$.

Unfortunately, none of the current biochemical or physiological explanations of disease resistance accounts satisfactorily for specificity. For example, accumulation of phytoalexins can be induced by a wide range of biotic and abiotic factors in a single host. Further, phytoalexins do not show the requisite specific toxicity toward pathogens. Possible exceptions to this may be found in instances where specificity lies at the host genus or family level and pathogens are tolerant in vitro (125), at least, to phytoalexins of the host. Finally, it seems clear that phytoalexin biosynthesis, as with other secondary metabolites, is under multigenic control. Thus, there is a need to search for an initial event (recognition) in pathogenesis, involving unique molecular species, that furnishes a signal (communication) for a biochemical response that in itself may be quite general.

\section{CURRENT MODELS}

Current discussions of recognition adhere to the above interpretation of the molecular genetics of resistance. In a simple model suggested by Ellingboe $(40,41)$, a specific host polypeptide interacts with one from an avirulent pathogen to form a dimer that then causes an incompatible response. This has the virtue of invoking direct products of genes in the complementary gene-forgene system required by Flor's hypothesis, but leaves the task of detecting the dimer and understanding the chemical basis of its action: for example, in causing the hypersensitive response associated with-but not necessarily causally related to $(19,95)$-resistance in many diseases.

Models suggested in the literature $(1,14,68)$ provide additional, often elaborate (14), details. These theoretical models are derived largely from studies of animal systems and the details vary somewhat depending on the plant disease under consideration and the particular expertise of the investigator. The following elements appear common to them.

1. The sensing organelles are excitable membranes, particularly the plasma membrane because it is a likely point of primary physical contact of host and pathogen or of pathogen-produced metabolites. For bacterial diseases, the sensing system may be the cell wall itself.

2. The chemical sensing devices are surface carbohydrates and/or integral membrane proteins or glycoproteins. Glycoproteins are especially appealing in this connection because of their role in animal cell recognition and the fact that carbohydrate residues may encode for different types of biological 
information than do amino acid residues. In recent years, plant lectins have been studied with increasing, and perhaps uncritical, frequency. Lectins discriminate among sugar haptens and "recognize" blood group antigens, but this probably is incidental to their function, if any, in plants.

3. A complementary (in a stereochemical or lock-and-key sense) pathogen molecule binds to the sensor transmitting a signal to the cytoplasm. Preferably, the pathogen molecule is a primary gene product, in strict adherence to Flor's gene-for-gene hypothesis.

4. The signal initiates metabolic responses leading to restriction of the pathogen.

Sequeira's use of the term recognition (110) allows for the possibility that the event triggered by initial recognition facilitates development of the pathogen rather than restriction or death of the pathogen. This might be considered an extension of the concept of self-recognition $(11,12)$, as opposed to the idea of recognition of non-self that is implicit in the immune response of higher animals and in the model given above for plant disease resistance. As discussed elsewhere (21), a priori choice between recognition of non-self and self for a particular disease should be avoided because such a decision may limit experimental protocols. A primary purpose here will be to examine both possibilities.

The concepts of recognition discussed above are variants or extensions of common chemical principles of cellular biology that are ingrained in our thinking. All cellular activity requires complementary chemical recognition at the metabolic level. Enzyme-substrate specificity, enzyme regulation by low molecular weight effectors, hormones, and secondary messengers are common examples where specific functional groups or stereochemistry dictates the direction and extent of cellular response to internal and external stimuli. There is no mystery about the fundamental principles that underlie recognition, although there may be in its application to cell-to-cell communication.

This review has three purposes: to examine selected biological phenomena outside the usual realm of plant pathology for precedents; to summarize recent data on plant diseases that suggest cell curface recognition; and to discuss other potential recognition devices for disease reaction.

\section{BIOLOGICAL PRECE.DENTS}

Many of the examples of recognition are described for animal systems, involving behavioral details with which I am not familiar. Therefore, the following comments are restricted first to phenomena, particularly pathologic processes, that bear on the biochemical validity of models for recognition in plant disease. 
Second, two important plant systems that can be related to disease resistance will be discussed.

\section{Biochemical Evidence}

The most direct documentation of surface chemistry that may be involved with recognition, particularly the role of carbohydrates, is with animal cells (45). This is at least partially owing to the fact that the structure of the plasma membrane of animal cells is well understood and its properties are consistent with a role in recognition. It exhibits functionalasymmetry in that carbohydrate moieties of component gangliosides are located on the external face. In addition, glycoproteins are integral membrane constituents. Structural details have been provided in a recent book (116).

Enzymes capable of transducing external signals also appear to be components of this membrane. Adenylate cyclase, responsible for the synthesis of the "second messenger," cyclic adenosine monophosphate (AMP), is one example (108). In the presence of guanosine triphosphate (GTP), several glycoprotein hormones activate membrane-bound adenylate cyclase, but not through direct binding to the catalytic protein itself. Rather, cyclase activation results from hormone binding to an additional regulatory membrane protein that then binds GTP, causing stimulation of cyclase activity. Hydrolysis of GTP turns off the cyclase. It is not yet established whether carbohydrate moieties are involved in the binding of the hormones.

A clearer instance of the importance of surface carbohydrates in triggering pathological cellular response is the binding of cholera toxin by the extemal monosialoganglioside, GM1 (98). Binding of toxin leads, as with the glycoprotein hormones, to stimulation of adenylate cyclase and an increase in cellular levels of cyclic AMP, which in turn results in accelerated leakage of ions, particularly chloride, accompanied by water flux.

Cholera toxin consists of two proteins associated by noncovalent bonding (A $=28,000$ daltons $; \mathrm{B}=56,000$ daltons) $(98,116)$. Protein $\mathrm{B}$ is involved only with binding to GM1 on the cell surface; it does not itself cause biochemical damage in target cells. Protein A is an enzyme capable of stimulating adenylate cyclase in the presence of nicotinamide adenine dinucleotide (NAD), cleaving the latter and transferring the adenosine diphosphate (ADP)-ribose product to the GTP-binding regulatory subunit of the cyclase. ADP-ribosylation modifies the regulatory subunit so that activating GTP is not hydrolyzed, leaving the cyclase in a persistently "turned-on" or unregulated state. The B protein appears only to facilitate the entry of the toxic A protein into the membrane (98, 116).

Several other bacterial toxins have functionally equivalent $A$ and $B$ subunit organization. In the case of diptheria toxin, the A protein also catalyzes NAD cleavage, but this results in inhibition of cellular protein synthesis by ADP- 
ribosylation of the elongation factor protein (EF2) of ribosomes (116). Interestingly, the highly toxic plant lectins, abrin and ricin, appear to act in a very similar fashion, including functional separation in these proteins of a binding domain and an enzymatic domain. In these cases, binding facilitates membrane transport rather than acting as a transducer of an external signal, as can be argued for adenylate cyclase activation by hormones. In either event, it is obvious that surface biochemistry is crucial for the toxic cellular response.

\section{Analogies from Plant Systems}

A major stimulus for much of the current interest in recognition and plant disease was the observation by Bohlool \& Schmidt (7) that soybean seed lectin agglutinated 22 out of 25 nodulating strains of Rhizobium japonicum. Certainly, their research drew attention to possible functions of lectins that until then had been curiosities, although diagnostically useful, in animal systems. Results subsequently obtained by Dazzo, Brill, and associates with $R$. trifoli on clover $(28,29)$ have been consistent with the notion that surface root lectins bind bacteria by complementary surface molecules as an essential and specific first step during infection in this symbiotic association. Despite (or perhaps because of) the extensive research on the topic, a number of current problems recently reviewed by Bauer $(5,6)$ and Vance $(124)$ must be considered. The most prominent are:

1. The correlations between binding to host lectin and nodulation usually are not perfect. It is possible that failure to get complete correlations is a result of the lack of formation of complementary binding molecules by certain strains under standard cultural conditions (109).

2. Most of the early studies employed seed lectin, but it has been difficult to establish the presence of lectin in roots, although such evidence is available for some clover (29) and soybean (47) cultivars. In contrast, a number of soybean varieties lacked lectin, but still nodulated effectively (105).

3. Binding of heterologous Rhizobia to roots is not an infrequent occurrence (5).

These uncertainties need to be resolved unambiguously, and they may have technical requirements, such as improvements in the isolation and detection of lectins. They illustrate, however, a major problem with correlative evidence (18). The single exception is a glaring one. Bauer (6) has suggested that binding per se does not impart specificity, as suggested by Dazzo (28), but may reside in one of several "signal-response" steps (perhaps involving lectins) during the progress of infection.

Development of the structurally and biochemically complex nodule requires coordinated interplay between host and symbiont, regulated by signals between 
them. Failure to send a signal or to respond by either host or symbiont could abort nodulation. This type of regulation has been suggested for obligate parasitism $(18,20)$. As noted elsewhere $(21)$, it is interesting that the primary thrust of biochemical investigations of symbiotic systems has been a search for factors promoting compatibility rather than incompatibility. Yet, as Vance has reemphasized (124), on the surface the processes of nodulation and disease share common principles.

A second plant system providing some precedent for recognition models in plant diseases is pollen-style interaction. The subject has been reviewed (16, 99), including an excellent comparison by Bushnell (13) of the genetics and physiology of disease and of self-sterility. Unlike the situation in legumeRhizobia interaction, there is a wealth of genetic information on pollen-style interaction; and Bushnell concludes that there is sufficient analogy to merit consideration of the principles involved (13). As with Flor's concept for host resistance, pollen-style incompatibility is governed by a dominant locus with several alleles. Unlike Flor's results, which indicated distinct but complementary nonallelic loci in the pathogen, incompatibility appears to occur when style and pollen share the same dominant allele. It has been generally assumed that an inhibitory or "oppositional" (99) event prevents fertilization. As early as 1929, East proposed (39) an "antibody-antigen" interaction that initiated the oppositional effect, and in the mid-1960s Lewis suggested (81), as for host-parasite interactions (40), that a polypeptide produced by both style and pollen forms a dimer that initiates incompatibility. Biochemically, however, such a model presents problems because, unlike the situation in disease, identical alleles in pollen and style should produce identical polypeptides, and the formation of a dimer should not require interaction between two cells once the gene is expressed. However, there is an abundance of surface molecules that might serve in recognition (16).

One form of self-sterility, gametophytic incompatibility, is expressed by the failure of the pollen tube to grow completely down the style, but the chemical determinants for failure are not clear. The extent of tube growth represents a continuum of development. Presumably influenced by the genetic data, the great majority of scientists assume an oppositional effect rather than a complementary one in which growth of the tube is dependent on the active support of stylar tissues.

Mulcahy \& Mulcahy recently have proposed a somewhat different complementary system, termed the heterosis model (99), based on a significant departure in the interpretation of genetic control of the phenomenon. Rather than a single dominant gene, they postulate a "supergene" consisting of several loci acting in concert. The loci may or may not be closely linked. It is further assumed that the loci of the supergene, which can be of any number (four are used in the simplest example), consist of at least one dominant and several 
deleterious recessive alleles. When pollen and style genotypes are paired, complementary recessive alleles are postulated to cause inhibition of tube growth, while complementary dominant alleles are neutral for growth. However, the combination of a dominant and a recessive locus would promote growth (heterosis). The sum of negative and positive (heterotic) combinations establishes the extent of pollen tube development. To greatly simplify their detailed arguments, a pollen genome of Abcd and a stylar genome of aaBBccdd would permit tube growth but Abcd and AAbbccdd would not. That is, the first case has heterozygous growth-promoting genetic elements $(\mathrm{Aa}, \mathrm{Bb})$, the second has none.

The underlying biochemical events can be thought of as being similar to those involved in the development of any normal tissue, but cell surface recognition need not be invoked as the major determinant for incompatibility. This particular hypothesis has been detailed in order to illustrate that the same set of genetic data can yield several sorts of genetic interpretations, and with quite different biochemical mechanisms. Such a model might have bearing on host-parasite interactions because, like self-sterility, resistance and susceptibility in certain diseases, such as rusts, are exhibited as a continuum of hostpathogen reactions (18).

\section{WALL AND CELL SURFACE COMPONENTS IN HOST-PATHOGEN INTERACTIONS}

The discussion that follows is limited primarily to research on host-pathogen systems on which there has been some sustained research effort and thus where there is additional information on various aspects (cytology, physiology, genetics) of pathogenesis. Isolated reports bearing on recognition, or those involving fungi or bacteria that are not pathogens, are abundant; but it is often difficult to place them in suitable context.

\section{Adherence of Bacteria to Hosts}

Attachment of Agrobacterium tumefaciens to a specific wound site has been suggested as an essential prerequisite for tumor formation induced in the host by passage of the Ti plasmid into cells. The evidence is based largely on the inhibition of tumor formation by cell walls and cell wall fractions (83). Virulent bacteria have been observed $(91,92)$ to attach more readily than avirulent strains and are subsequently enveloped by fibrils of their own elaboration that entrap additional bacteria. This suggests that only virulent bacteria may produce a specific factor involved with attachment, but the chemical nature of the factor is as yet unknown.

Rao et al (107) have reported that pectins from various sources, as well as polygalacturonic acid (PGA) polymers, are inhibitors of tumorogenesis in 
Pinto bean leaves, with PGA the most effective. Methylation of PGA appears to reduce its inhibitory action, providing potential explanations for the lack of tumorogenesis in transformed cells and embryonic tissues of host plants (84). Pueppke \& Benny (104) have been able to confirm the inhibitory effects of pectins and PGA with a potato tuber assay but observed no significant differences caused by the extent of methylation, even though the same bacterial strain was used in both laboratories. In addition, they have been unable to show an inhibitory effect on tumorogenesis by bacterial lipopolysaccharide (LPS) as reported earlier with the Pinto bean assay $(107,134)$, even when LPS was supplied (104) in great excess relative to the amount of LPS in the bacterial inoculum. Unless resolved, the differences in behavior in the two assay systems suggest the absence of a common type of attachment. This is surprising given the ubiquitous pathogenicity of Agrobacterium on dicot hosts. Further, Matthysse et al (93), using a filtration assay to estimate unattached bacteria (91), found that attachment, followed by fibril formation, occurred with isolated carrot cell protoplasts treated to prevent cell wall regrowth. Kinetically, the binding was indistinguishable from that to intact carrot cells, but whether nascent polysaccharide chains were present on the membranes was not determined. Arivulent bacteria did not attach to protoplasts and PGA did not cause inhibition of binding by virulent bacteria.

Thus, the mechanism of attachment is at present uncertain. Pueppke et al (105) found that 22 strains of $A$. tumefaciens did not bind flourescein labeled lectin. However, labelled concanavalin A bound to 2 oncogenic and 1 nononcogenic strains of the 22 tested (106).

The binding of bacteria to the walls of resistant plants has been a controversial subject. Goodman et al (54) described a sequence of events, including fibril formation, that is similar to that for A. tumefaciens but with a non-pathogen, Pseudomonas pisi, inoculated into leaves of tobacco. Sequeira et al (112) reported that avirulent or incompatible $P$. solanacearum strains had a similar sequence in the same host species but virulent bactcria were not observed to attach. Hildebrand et al (63) have argued that these results may arise as an artefact of preparation for electron microscopy. Compatible infections usually lead to water soaking of tissues, and it was suggested that incompatible bacteria could be entrapped at air-water interfaces created in resistant tissues with less intercellular fluid.

To provide more direct evidence for binding, Sequeira \& Graham (113) investigated agglutination of virulent and avirulent Pseudomonas solanacearum strains by lectin from host potato. The correlations were excellent: 34 avirulent strains were agglutinated and 55 virulent strains only weakly or not at all. Further, the lack of agglutination of virulent bacteria was correlated with the presence of extracellular polysaccharide (EPS) that, when removed by washing, resulted in agglutination. Direct binding of flourescein-labelled lectin 
to virulent cells was established and was prevented by chitin oligomers, in keeping with the hapten specificity of potato lectin. In addition, immunoflourescent staining revealed lectin in the mesophyll cell walls in potato and tobacco (77). The overall results strongly suggest a glycoprotein-carbohydrate recognition process in this disease.

Surprisingly, further purification of potato lectin (78) resulted in successive loss of agglutinating activity and led to the discovery of a distinct hydroxyproline-rich glycoprotein (HRGP) bacterial agglutinin in the lectin preparation. HRGP does not have hemagglutin activity characteristic of lectins, suggesting that binding is not hapten mediated. Mellon \& Helgeson (96) have extracted a similar HRGP from tobacco suspension cells that also binds to the avirulent strain B-1 of Pseudomonas solanacearum, but not to the virulent strain K-60. Tobacco HRGP agglutinated both virulent and avirulent strains of Phytophthora parasitica. Although 34 potential haptens were tested, no soluble carbohydrates prevented agglutination, but high ionic strength media did. These results imply a charge-dependent surface binding. If the results can be extended to the HRPG isolated from potato, which is very basic (78), the pathological significance of binding may have to be reexamined. HRGP are present widely, if not universally, in higher plants and would not be expected to play a significant role in host specificity. However, bacterial lipopolysaccharide may be an important component of host-pathogen interactions (55), since by itself it appears to induce a resistance response.

\section{Spore Agglutination Factors}

Kojima \& Uritani $(72,128)$ reported the ability of plant extracts to preferentially agglutinate spores of non-pathogenic strains of Ceratocystis fimbriata. Sweet potato tuber extracts agglutinated spores of $C$. fimbriat $a$ strains attacking coffee, prune, cacao, oak, taro, and almond, but not the compatible sweet potato stain. Extracts from taro and cucumber showed similar, but not perfect, correlations of agglutination and incompatibility. Extracts from kidney bean exhibited strong correlations with disease reaction; spores of three nonpathogenic strains were agglutinated, but not those of four compatible ones (72). Unfortunately, these most interesting combinations apparently have not been studied further. Rather, attention has focused on factors in sweet potato and to some extent taro root (66).

A glycoprotein-like factor was isolated from sweet potato $(73,74)$ that required $\mathrm{Ca}, \mathrm{Mn}, \mathrm{Ni}$, and $\mathrm{Mg}$ for agglutinating activity, but the activity was not specific. Spores of all strains, including sweet potato, were equally affected. The factor also agglutinated rabbit erythrocytes. However, unidentified compounds of low molecular weight partially restored the differential effect previously described (73). An apparently different spore agglutinin was described more recently (71). It is composed mainly of galacturonic acid (50\%) along 
with other minor sugars, contains less than $1 \% \mathrm{~N}$, and agglutinated all blood group types of human erythrocytes, suggesting that sugar hapten recognition is not involved. $\mathrm{Ca}$ ions were required for all agglutinating activities. Unlike previous observations $(73,74)$, there were no differential effects with ungerminated spores of $C$. fimbriata pathogenic strains. At $\mathrm{pH} 6.5$, germinated spores of the sweet potato and almond strains were not agglutinated; the others were and to somewhat different degrees. At 5.5 and $7.5 \mathrm{pH}$ even the germinated spores of the sweet potato strains were agglutinated (71). Demonstration of selective agglutination thus requires rather specific conditions ( $\mathrm{pH}$ and $\mathrm{Ca}$ ) that were not observed earlier. Whether these conditions occur during infection is not known. A similar factor for germinated spores has been isolated from taro tuber (66) and is $\mathrm{pH}-$, but apparently not Ca-, dependent. Treatment of germinated spores with pronase, phospholipase $\mathrm{D}$, and macerozyme reduced differential activity, suggesting an action on cell surfaces. At present, it is difficult to sort out the important factors in this phenomenon.

\section{Induction of Phytoalexins}

On the assumption that phytoalexin accumulation is a valid index of resistance, a number of studies relating to recognition have been described from several laboratories. Research in the laboratory of Peter Albersheim $(2-4)$ has resulted in the demonstration of glyceollin accumulation in soybean cotyledons treated with polysaccharide fractions isolated from culture filtrates or extracted from cell walls of Phytophthora megasperma var. glycinea (Pmg) (in the older literature var. sojae). The fractions were effective over a similar range of concentrations of applied carbohydrate, presumably because they share a common component, most likely the glucan moeity subsequently purified. An interesting observation (3), as yet unamplified, was that $\alpha$-methyl-D-mannopyranoside at a ratio of $20: 1$ by weight inhibited phytoalexin accumulation by $90 \%$, but the corresponding glycosides of galactose or glucose had little or no effect. However, $\alpha$-methyl-D-glucopyranoside prevented the inhibitory effect of $\alpha$-methyl-D-mannose (3).

These studies are a good example of the potential for the induction of cellular responses by cell surface interactions mediated by carbohydrates. Unfortunately, in this instance there was little specificity associated with either the host response or the cell wall composition of the fungus. Races 1, 2, and 3 of Pmg yielded nearly identical polysaccharide fractions with quantitatively indistinguishable biological responses (3). Fraction I from race 1 significantly increased the phenylalamine lyase (PAL) activity in suspension cell cultures of the cultivars Harosoy and Harosoy 63, which are incompatible and compatible to race 1 , respectively. In addition, fraction I stimulated PAL in parsley and sycamore cell cultures (3). The finding that phytoalexin accumulation was identical with fraction I alone or in the presence of a compatible or incompatible 
race, but had no effect on disease reaction, is unexpected but has a profound, although generally unacknowledged, bearing on the role of phytoalexins in resistance responses.

More recently, Wade \& Albersheim (128) described the isolation of glycoproteins (approximately $80 \%$ protein and $20 \%$ carbohydrate) from culture filtrates that appeared to exhibit race specificity in the Pmg-soybean system. Preparations from incompatible races protected susceptible plants from infection by compatible races when applied prior to inoculation at dosages of 10-100 $\mu \mathrm{g} / \mathrm{ml}$. Carbohydrate analysis indicated apparently significant differences in the proportions of mannose, glucose, and galactosamine of glycoproteins from races 1,2 and 3 (128), implying that the specificity of the response may lie at least partially in the carbohydrate components. Although the relative percentages of component carbohydrates generally were similiar to those in some earlier fractions causing phytoalexin accumulation, accumulation did not occur with these glycoproteins. However, a later report by Desjardins et al (30) found a lack of protection with the same glycoproteins. The reason for the negative findings is obscure, but it was suggested to result from variation in seed lots or from unknown microclimatic factors during assay (30). Further research on the system clearly is important. A related observation arises from the work of Ziegler \& Pontzen (142), who reported that purified extracellular invertase of Pmg race 1 suppresses glyceollin accumulation in compatible, but not in incompatible, cultivars. Invertase from race 3 , compatible with the three cultivars tested, inhibited glyceollin accumulation in all three cultivars. In all instances, glyceollin accumulation was non-specifically induced by a glucan isolated with methods very similar to those of Keen \& Legrand (69) discussed below. The unusual choice of invertase in these experiments stems from the earlier work of Zeigler \& Albersheim (141), which describes differences in the carbohydrate composition of invertases isolated from culture fluids from races 1,2 , and 3 of Pmg. The protocol as described (141) does not permit a distinction between differences resulting from true genomic differences or from differences arising from culture variability. The ratios of mannose to glucosamine are quite different in the preparations of Zeigler \& Pontzen (race 1, 18:1; race 3,21:1) than in invertases prepared by Zeigler \& Albersheim (Race 1, $7.6: 1$; race $3,3.1: 1$ ). Such large differences in supposedly identical molecules raise questions about the importance of carbohydrate composition in these phenomena.

In contrast to the reports of non-specific induction of phytoalexin accumulation in soybean, there are several reports of specific accumulation. Low molecular weight fractions were prepared from Pmg by Keen in 1975 (67), but the observations have not been amplified and were not discussed in a recent review (68). Bruegger \& Keen (10) subsequently extracted the cellular envelopes of Pseudomonas glycinea from several races using sodium dodecyl 
sulfate and obtained glycoprotein-containing fractions that caused apparently specific accumulation in incompatible hosts. The number of critical comparisons was limited and the correlations were not perfect. For example, solubilized envelope preparation from race 1 induced $19 \mu \mathrm{M}$ glyceollin on Harosoy (incompatible) and 7.3 $\mu \mathrm{M}$ on compatible Acme. Preparations from race 6 induced $14.6 \mu \mathrm{M}$ on incompatible Harosoy, but only $3.6 \mu \mathrm{M}$ on Acme, which also is incompatible to race 6 . Acme had appreciably lower response to envelope preparations from races 2 and 4 than did Harosoy, but both cultivars are compatible with these races. Thus, it is unwise to generalize in this instance until more data, amenable to statistical analysis, are available. The use of concentration units $(\mu \mathrm{M})$ stems from the procedure of measuring only the glyceollin apparently diffusing onto the tissue surface, a departure from usual procedures. Presumably this estimates only the activity induced in cells in contact with macromolecules. Nonetheless, knowledge of the tissue concentrations is of great interest and would be instructive in relation to other studies.

Keen \& Legrand (69) extracted Pmg cell walls with methods (42) chosen to preserve glycosyl-protein bonds. Indirect evidence was presented to show that the preparations were cell-surface glycoprotein and the importance of the sugar residues was emphasized by the loss of activity in inducing glyceollin accumulation after periodate oxidations. Unlike the glycan elicitor reported by Albersheim and colleagues, amounts in the range of $1-5 \mathrm{mg} / \mathrm{ml}$, rather than $\mu \mathrm{g} / \mathrm{ml}$, were required for activity. Although the appropriate comparison was shown with replicated rials for a single preparation on paired compatible and incompatible cultivars (e.g. race 1 fractions on Harosoy and Harosoy 63), the variation is high. On the average, compatible lines produced lower amounts of glyceollin than did treated incompatible hosts. As noted by the authors, considerable variation could be expected to arise from several factors, but increased replication obviously is desirable. One puzzling aspect of the specificity claimed in these studies is that Zeigler \& Pontzen (142) used nearly identical procedures with Pmg walls, but they resulted in a preparation from race 1 that was used routinely by them to induce glyceollin production in both compatible and incompatible cultivars. Zeigler \& Pontzen extracted Pmg walls with $0.2 \mathrm{M} \mathrm{NaOH}$, as originally recommended by Falcone \& Nickerson (42), plus $5 \mathrm{mM}$ dithiothreitol, rather than only $0.1 \mathrm{NaOH}$ used by Keen \& Legrand (69). Certainly the difference in extractants might account for the differences in a very important biological property, but it does point out the need for care in describing protocols in order to reduce some of the existing controversy over results on this host-parasite system. Finally, Gibson et al (51) have reported higher amounts of soybean agglutinin in a resistant cultivar, but a total of only two cultivars was examined.

Hadwiger \& Loschke (60) have reviewed experiments purporting to show that the common fungal polysaccharide chitosan is an important component in 
the response of pea to F usarium solani f. sp. phaseoli, a non-pathogen, when contrasted with the pathogen $F$. solani f. sp. pisi (58). Chitosan is a nonspecific inducer of the phytoalexin pisatin in pea pods $(57,100)$. It is also an effective inhibitor of the development of infection propagules of $F$. solani, since $62 \mu \mathrm{g} / \mathrm{ml}$ is completely inhibitory for 24 hours and $125 \mu \mathrm{g} / \mathrm{ml}$ for 66 hours (57). Hadwiger \& Beckman (57) present a table indicating that treatment with chitosan at the time of inoculation leads to a resistant, rather than a susceptible, reaction at seven days. These results, however, were obtained by application of $10 \mathrm{mg} / \mathrm{ml}$ chitosan, far above the amount required to inhibit propagule development for nearly three days (57).

It is difficult to explain specificity in terms of a very common fungal wall component that acts independently to induce resistance and to inhibit fungal growth, since compatible and incompatible races both have chitosan. Hadwiger $\&$ Line (59) have reported an accumulation of chitosan in tips of the terminal growth of Puccinia striiformis, where presumably it might act to induce resistance and simultaneously regulate or inhibit fungal growth. However, this is clearly a secondary event in resistance. It should be noted, however, that both chitin and chitosan content vary with development of rust fungi. Polymeric forms of glycosamine were not detected in the spores of the rust fungi, but could be detected in germ tubes on the surface of inoculated leaves (94). During the first four days of infection, additional polymeric glucosamine could not be detected chemically (94).

In an interesting approach to understanding resistance to $F$. solani $\mathrm{f}$. sp. phaseoli by peas, Wagoner et al (129) labelled polypeptides in vivo and recorded 21 proteins that increased 4-8 hours after inoculation with incompatible $F$. solanif. sp. phaseoli and with chitosan treatment. Surprisingly, the same patterns were observed with compatible f. sp. pisi. Translation of mRNA isolated from the tissue appeared to result in the same polypeptide patterns (129). At 24-96 hours, these patterns persisted with both incompatible f. sp. phaseoli and with chitosan treatment, but the compatible Fusarium-pea combination had additional polypeptides that did not appear to be the result of pathogen polypeptide synthesis (62). Because it had been concluded from early work (61) with inhibitors of protein and RNA synthesis that significant events in pathogenesis involved enzyme synthesis only in resistant tissues 4-8 hours after inoculation, these results were not expected.

Obviously, these studies are in a beginning stage. The techniques may not resolve polypeptides uniquely associated with resistance. If the gene-for-gene concept is applicable to this system, it is difficult to ascribe pathological significance to the large number of polypeptides found to increase in both compatible and incompatible hosts. Young et al $(139,140)$ reported that chitosan, along with other polycations and polyanions, caused leakage of calcium from cell walls, but that only polycations such as chitosan affected 
membrane properties. The general nature of the responses they observed with polycations indicates that the effect of chitosan is chemically non-specific. The results on polypeptide synthesis in the early stages of infection can be interpreted best as a general cellular response to any biological or chemical irritant (19), followed by the induction of compatible response in susceptible tissue (18). The initial cellular response need not be an active resistance.

\section{Suppressors of Resistance}

Work by Varns \& Kuć [summarized in reference (127)] show that cell walls of compatible and incompatible races of Phytophthora infestans contain components that non-specifically induce phytoalexin accumulation in potato tissues. It now appears that at least part of this activity of wall fractions may be due to the presence of the potent lipid elicitors, arachidonic and iecosapentaenoic acids (8). It is interesting that these compounds do not appear to be active on soybean tissues.

Doke (32) obtained a high molecular weight fraction from zoospores that, when applied to tubers of compatible potato cultivars 18 hours before inoculation with an incompatible race, markedly reduced the browning characteristic of the hypersensitive response. Garas et al (48) extended these observations to mycelial wall preparations and showed suppression of phytoalexin accumulation induced by infection with the incompatible race or by elicitors prepared from Phytophthora walls. Suppression of rishitin and lubimin was not complete. The most effective treatment caused approximately $85 \%$ suppression of rishitin in one experiment, while in the same test lubimin accumulation was not suppressed at all. The suppressors consisted of anionic (containing phosphate) and non-ionic glucans with B-1,3 and B-1,6 linkages (33). The degree of polymerization was approximately 20 for both glucans obtained from zoospores and from mycelium of races 1234 and 4 (33). As with Doke's original work, effective protection appeared to require application several hours before inoculation. Mixing glucans with elicitor had little effect on inducing activity (33). As noted by the authors (33), studies with additional race and host combinations are needed before a role for the glucans can be determined.

Doke \& Tomiyama (34) extended these observations with protoplasts, not tuber slices, prepared from nine potato cultivars and with glucans obtained from seven races, using induction of abnormal protoplast changes by cell wall fractions from Phytophthora as an index. There was a tendency for glucans from compatible races to prevent cell damage, but the amounts of glucan applied were quite high $(10 \mathrm{mg} / \mathrm{ml})$ and protection was never better than $52-53 \%$.

\section{Macromolecules in Other Host-Parasite Systems}

Dow \& Callow (35) could not confirm an earlier report that glycoproteins produced in culture by strains of Cladosporium fulvum specifically damaged 
incompatible tomato hosts. DeWit \& Spikman (31) have found that intercellular fluids of compatible tomato contain materials, not yet characterized in detail, that cause necrosis only on incompatible uninfected tomato cultivars. Such materials apparently are not found or produced in culture. Failure to find similar materials in infected, incompatible tissue may merely be the result of the development of a smaller amount of infected tissue after inoculation, thus limiting detection. Whether they are pathogen- or host-produced is unknown; if the latter, what function they play in resistance is uncertain.

\section{Comments}

The current evidence for specific recognition involving high molecular weight components is quite limited, perhaps as a consequence of experimental difficulties. In general, the preparations of active species in most cases are relatively crude; this may cause "masking" of any molecular species with requisite high selectivity and innate activity. One disturbing aspect of the current literature is the extremely large dosages applied for most bioassays. A concentration of 1 $\mathrm{mg} / \mathrm{ml}$ of mycelial wall fragments or glycoprotein represents a considerable amount of wall or cell membranes, if one considers that an incompatible reaction in a natural infection is caused by a microscopic mass of fungal hyphae or bacterial cells. In most cases, it is difficult to determine from the protocol what the relationship is between the weights of materials applied and the weight of pathogen from which it is obtained, an absolutely necessary consideration if the results are to be validated biologically.

For the obvious reason of saving time and space, there is an increasing tendency to study recognition with laboratory procedures that may or may not be a true reflection of disease resistance. It is still an open question whether phytoalexins are effective in resistance or whether their production is a general symptom of cellular stress. The observed lack of specificity in some of the experiments described above (and probably in many unpublished ones) may have their origins, not in the lack of purity of fractions, but in the nature of the assay (phytoalexins, hypersensitive response, etc). It is also true, however, that obtaining a positive correlation between specificity and a chemical response of tissue in such experiments is an acceptable proof for the role of that particular response in nature. For completeness, however, it should be accompanied by sound biological proof that resistance indeed has been induced in tissues when treatment is followed by inoculation with a compatible pathogen. The most convincing proof would be based on application of the inducer at or, better, subsequent to inoculation of the compatible host. Prior reatment may result in non-specific inhibition arising from cellular injury (19). It is important to comment that the glucan elicitor isolated from Pmg by Albersheim and colleagues will protect compatible soybeans when they are pretreated with it, but not when applied at inoculation. Remarkably, phytoalexin production is nearly identical in incompatible and compatible combinations when glucan is supplied 
at the time of inoculation. Although the results can be interpreted in a number of ways (3), they serve as a reminder that acceptance of a recognition mechanism requires relating the mechanism to all of the disease syndrome, not an isolated process of it.

Verification of positive findings by other independent scientists is limited. The establishment of sound scientific principles requires independent confirmation by repetition of key experiments or by subsequent convincing amplification of results, and there are surprisingly few reports of either type.

\section{Host-Selective Toxins}

The existence of host-selective or specific toxins was first established clearly approximately 35 years ago in the case of Helminthosporium victorae attacking oats with the Victoria gene for resistance to crown rust (victorin or HV-toxin). In recent years, the number of diseases in which host-selective toxins (HST) appear to be involved has expanded to about fifteen. Several books $(23,36)$ and reviews $(24,52,88)$ summarize recent advances in this field.

The taxonomic distribution of affected hosts includes both dicots and monocots, but it is important to note that the pathogens involved are primarily species of Alternaria affecting dicots and Helminthosporium affecting monocots. Why this is so is not clear. It may indicate the evolution of a unique mode of pathogenesis by these fungal species. If this is the case, their importance for discussion of recognition phenomena in plant diseases is of limited value. However, it is possible that the current imbalance in favor of these two species is merely the outcome of the general protocol that has been used to establish the production of toxins by microorganisms: the testing of culture medium in vitro. Alternaria and Helminthosporium may be metabolically unusual in their ability to synthesize in vitro the same metabolites that are important in vivo. The amount of toxin produced must be sufficient to be detectable above the background levels of non-specific toxicants, primarily common products of secondary metabolism. All HST purified so far have remarkable innate toxicity, nearly always between 1 and $10 \mathrm{ng} / \mathrm{ml}$, which facilitates detection in dilutions of crude culture filtrates. It is the author's opinion that with the marked improvement in separation techniques in recent years, it will soon be possible to extend the list to other genera, even in the case of compounds of much lower specific toxicity. With better analytical and separation techniques, it may also be possible to examine infected tissue directly, rather than rely on the ability of fungi to produce HST under artificial conditions, as is now the case.

Past research on HST has been handicapped by the absence of knowledge about their structure and hence their purity. The first plausible structure of an HST, from A. mali affecting pear, was deduced in 1975. Between 1979 and 1983, however, structures of five more have been elucidated [see (88) for a 
concise summary]. As a consequence, some of the earlier notions about their biological significance and mode of action may have to be reconsidered, but now it is possible to begin to understand the chemical features of these toxins that govern specificity.

Earlier work had suggested that peptide bonds might be a common feature of host-specific toxins. The HST of $A$. mali is a mixture of cyclic depsipeptides (Figure 1), but only the HST of $H$. carbonum has a true peptide structure (Figure 2). The latter contains an unusual amino acid, 2-amino-8-oxo-9,10 epoxydecanoic acid (AOE). In the case of the HST from $H$. carbonum, there is only a single molecular species for which there are three possible arrangements of the constituent amino acids (Figure 3). In the first published description, Liesch et al (82) concluded, on the basis of mass spectra, that HC-toxin was represented by structure III. Independently and by different methods, joint research at Nebraska and Purdue universities also established the presence of the unusual amino acid AOE. However, on the basis of peptic digests, and especially a novel mass spectral technique, Pope et al (103) and Gross et al (56) demonstrated unequivocally that the structure shown as I in Figure 3 is correct. A third group at Cornell (131) also reached the same conclusion.

AOE is present in three other antibiotic cyclic tetrapeptides produced by species of the fungi Petreilla (the antibiotic WF-3161) (122), Diheterospora (chlamydocin) (17), and Clyindrocladium (Cyl-2) (64). Like HC-toxin, chlamydocin contains proline, while WF-3161 and Cyl-2 have the related pipecolinic acid, indicating similar pathways of biosynthesis. Only HC-toxin contains alanine (Figure 2). All three antibiotics have antitumor activity, and the antibiotic properties of chlamydocin are lost if the terminal epoxide ring of AOE (Figure 3) is destroyed (17).

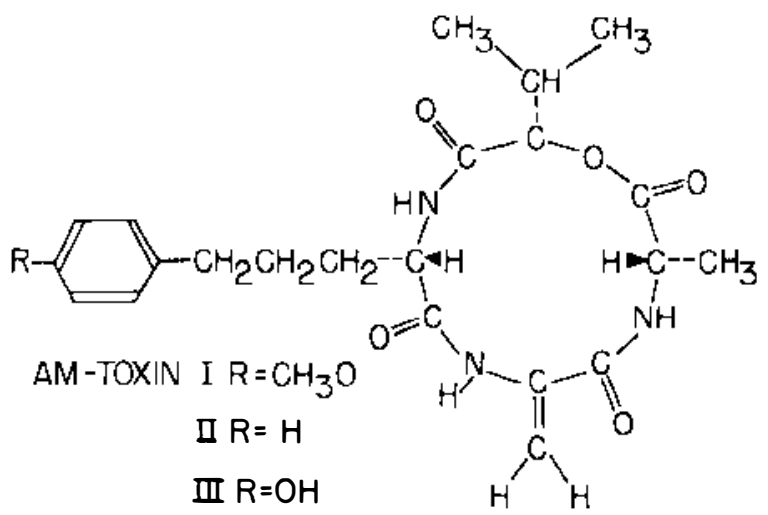

Figure 1 A. mali toxin affecting apple (121). In order of toxicity the three natural analogs are: Am-toxin 1, R-1 $\mathrm{OCH}_{3} \mathrm{X}=\mathrm{CH}_{2}$, AM-Toxin III, $\mathrm{R}=-\mathrm{OH}, \mathrm{X}=\mathrm{CH}_{2}$; AM-Toxin II, $\mathrm{R}=-4, \mathrm{X}$ $=\mathrm{CH}_{2}$. Other substitutions at these positions were much less active (121). 


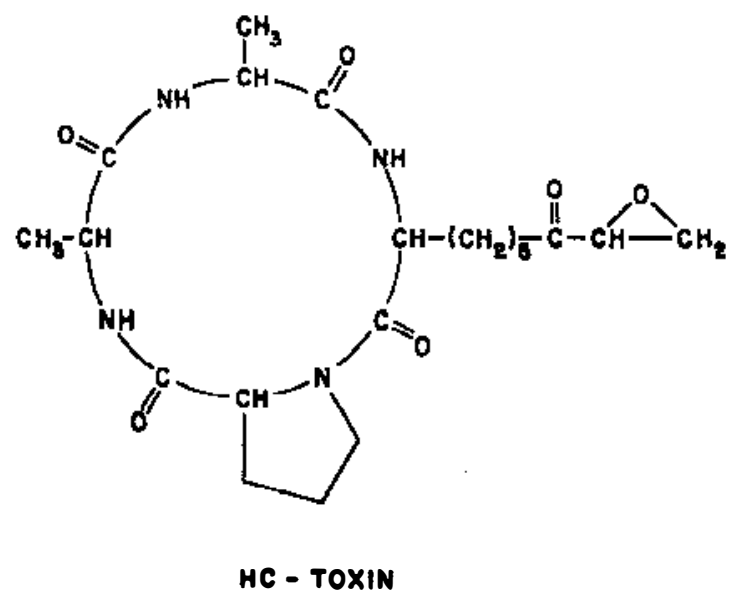

Figure $2 H$. carbonum toxin affecting com $(15,82,103)$.

The importance of the epoxy group in HC-toxin toxicity to susceptible plants was demonstrated convincingly with the isolation by Cuiffetti et al (15) of an "inactive conversion" product that differs only from the active form by the opening of the epoxy ring (Figures 2,3 ) to produce hydroxyl groups at carbons 9 and 10. Detailed analysis of nuclear magnetic spectra failed to show any other spectral differences between active and inactive forms, indicating no change in conformation of the peptide (15) ring. The inactive species did not protect against, or compete with, the active toxin. Walton \& Earle (130) also believe that the epoxide group is important for toxicity, but their evidence is not definitive. The inactive conversion product appears to represent (103) approximately $40 \%$ of the toxin purified by Walton et al (131). Treatment of this preparation with $1.0 \mathrm{HCl}$ in methanol inactivated the toxin completely (130). This treatment does cause opening of the epoxy ring, but it apparently produces
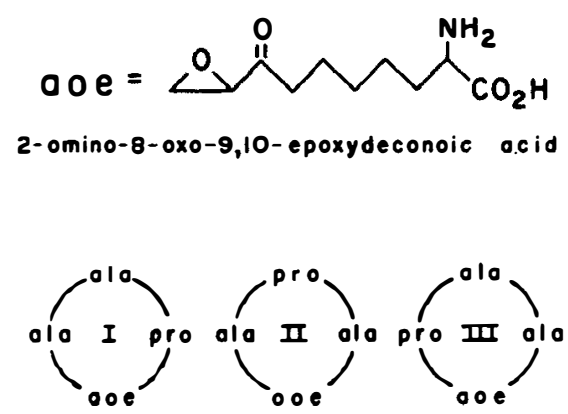

Figure 3 Three possible arrangements of amino acids in HC-toxin. Structure III is correct for the natural toxin $(56,103,131)$. 
a mixture of six compounds and other important changes in the peptide ring. Nuclear magnetic resonance spectra bearing on this point were not obtained (130).

It should be kept in mind in this and subsequent discussion that specificity and toxicity may not be necessarily the same. The epoxy group of HC-toxin clearly is important for toxicity, but specificity may reside in other functional groups of the molecule. It would be of great interest to compare the three similar cyclic peptides from other fungi on corn varieties resistant and susceptible to $H$. carbonum, along with possible synthetic variants (i.e. structures II, III, Figure 3) of $\mathrm{HC}$ toxin itself.

Unlike AM- and HC-toxins, the other structurally characterized HST lack peptide bonds. They are structurally quite diverse and appear to be ordinary products of secondary metabolism. Three examples are shown in Figure 4.

Again unlike HC-toxin, the other HST consist of several distinct molecular species (Figures 1, 4). Although distinct species could be artif acts of isolation, the nature of the variation observed is consistent with variation arising from biosynthesis. In either event, their existence provides a starting point for analysis of structure-specificity relationships.

Three analogs of AM-toxin (Figure 1) are found naturally, but AM-toxin I is approximately 10 times more active than II, with AM-III of intermediate inactivity. Laboratory syntheses (121) provided a number of variations from the structure of AM-I but none was even as active as AM-II. Similarly, the toxin of $H$. sacchari consists of three isomeric forms involving unsaturation at carbon 4 of the sesquiterpene ring (Figure 4, middle), as reported by Macko et al $(89,90)$. Duvick et al $(37)$ have shown that the most abundant isomer, $\mathrm{C}$ (Figure 4), is approximately 6 and 9 times more toxic than isomers B and A respectively, and can account for nearly all the specific toxicity observed in culture filtrates. Reduction of the methylene group at carbon 12 of the side chain of isomer $\mathrm{C}$ leads to two forms of the isomer due to differences in planar orientation of the methyl group so formed at carbon 12 . One form is nearly as active as the original isomer $\mathrm{C}$, the other appears to be non-toxic (37a). Unfortunately, the absolute configurations have not been established.

These findings indicate quite nicely that very subtle structural changes in HS-toxin cause marked difference in toxicity. Just as interesting are the activities of lower homologs found in culture filtrates and arising by loss of 1 , 2 , or 3 galactose $(86,89,90)$ units by the action of an extracellular galactosidase (87), which randomly cleaves the $B$-galactofuranosyl linkages of the disaccharides attached to the sesquiterpene ring (Figure 4). Homologs lacking 1,2 , or 3 galactose units (designated $\mathrm{HS}_{3}, \mathrm{HS}_{2}$, or $\mathrm{HS}$, respectively) $(37,88)$ are nontoxic to susceptible sugar cane $(37,86)$. A brief report $(85)$ indicated that they protected tissue from damage by active toxin. Duvick et al (37) showed that the molar ratio of protectant to toxin required to give nearly 


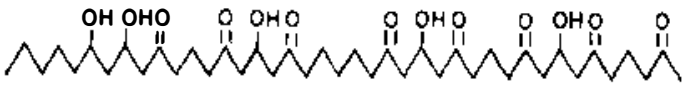

Band $\mid\left(C_{A \mid}\right)$

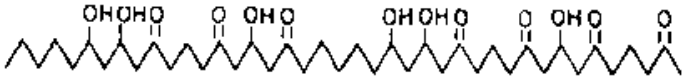

Band $2\left(\mathrm{C}_{41}\right)$

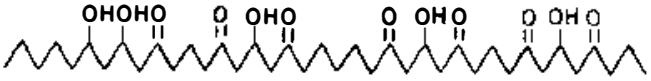

Band $3\left(\mathrm{C}_{39}\right)$

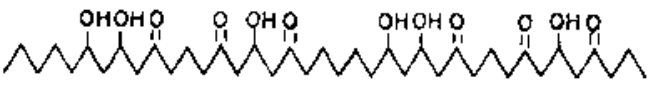

Bond I' $\left(C_{39}\right)$

HMT-TOXIN, mojor components<smiles>[R20]CC(=C)C1CCC2(C)CC([R6])C=C(C)C2CC1CO</smiles>

HS-TOXIN

$R=5-0-(B-g o l o c t o f u r a n o s y l)-B-$ goloctofuranoside<smiles>[Y]C(CCCCCCCC(O)C(O)CC(O)CN)C([X])C(C)CC</smiles>

$$
\text { II } X=O H, Y=O H, X=0 \text { - } Y \text { - }
$$

Figure 4 Chemical features of three HST. Top: the four main components of toxin from $H$. maydis race $\mathrm{T}$ affecting com with Texas male sterile cytoplasm (75); middle: toxin from $H$. sacchari attacking sugarcane $(89,90)$; bottom: toxin from $A$. alternaria $\mathrm{f}$. sp. lycopersici affecting sugar cane $(9,53)$. The individual components of $\mathrm{HmT}$ - and AAL-toxins are all equally toxic and specific. 
complete protection was 50:1, 6:2, and 15:1 for $\mathrm{HS}_{1}, \mathrm{HS}_{2}$, and $\mathrm{HS}_{3}$. Since the lower homologs are biologically active as protectants, although non-toxic, the results can be interpreted to mean that the sesquiterpene ring functions in binding while the toxicity may lie with the galactofuranose groups. Contrary to previous reports (117), $\alpha$-galactopyranosides were not effective as protectants even at a molar ratio as high 500:1 (37), but $\beta$-galactofuranosides were (37a). The requirement of four galactofuranosyl residues for toxicity is emphasized by the finding that another component obtained from culture filtrates possesses an additional glucosyl residue as a terminus of each of the galactose disaccharides. Only slightly toxic, if at all (37), this compound does not protect against toxin. These structural constraints on toxicity suggest that HS-toxin probably interacts with a chemically distinct host at a well-defined locus of small molecular dimensions.

HmT-toxin from $H$. maydis race $\mathrm{T}$ consists of approximately 10 linear polyketols $(75,76)$, varying in length of the odd-numbered carbon chains $\left(\mathrm{C}_{35}-\mathrm{C}_{45}\right)$ and in the degree of reduction for a given chain length. Four of the individual species $\left(C_{39}\right.$ and $C_{41}$ chain lengths, Figure 4$)$ constitute $70-90 \%$ of various preparations of toxin. In contrast to AM- and HS-toxins, all components of this toxin appear to possess equal toxicity and specificity. In the original report, Kono \& Daly (75) noted that the chain lengths approximated the width of a lipid bilayer and length might be important for activity.

The unrelated fungus, Phyllosticta maydis (PM), produces a toxin of similar specificity toward com with Texas male sterile (TMS) cytoplasm. Recent studies by Danko et al (26) have shown that this toxin comprises 12-15 linear B-ketoalcohols, of which the four most abundant are shown in Figure 5. These are shorter in length $\left(\mathrm{C}_{33}\right.$ and $\left.\mathrm{C}_{35}\right)$ and have different oxygen functions when compared to Hmt-toxin (Figure 4).

$\mathrm{C}_{15}-\mathrm{C}_{25}$ analogs of Hmt-toxin synthesized by Suzuki et al (118) were shown to possess specific toxicity but at lower molar concentrations (119). Subsequently, a $\mathrm{C}_{41}$ analog (118) was found to have toxicity identical to native HmT-toxin. Suprisingly, it was about 300 times more active than the $C_{25}$ analog (118). These results reinforce the notion that chain length is of considerable importance in toxicity and specificity.

It is somewhat surprising, therefore, that each PM-toxin component is as toxic, perhaps more so (26), as the components of Hmt-toxin, despite the fact that they have shorter chain lengths and fewer oxygen functions (Figures 4, 5). However, construction of space-filling models suggested a common base for their toxic and selective activity. The common features are illustrated in Figure 6 . When the molecules are aligned, it can be seen that the oxygen functions of PM-toxin A are spaced identically with HmT-toxin 2 (Figure 1) and with the synthetic $\mathrm{C}_{41}$ analog prepared by Suzuki (118). Only two sets of the oxygen functions of the leak patent and shorter $\mathrm{C}_{25}$ can be aligned with HMT-toxin 


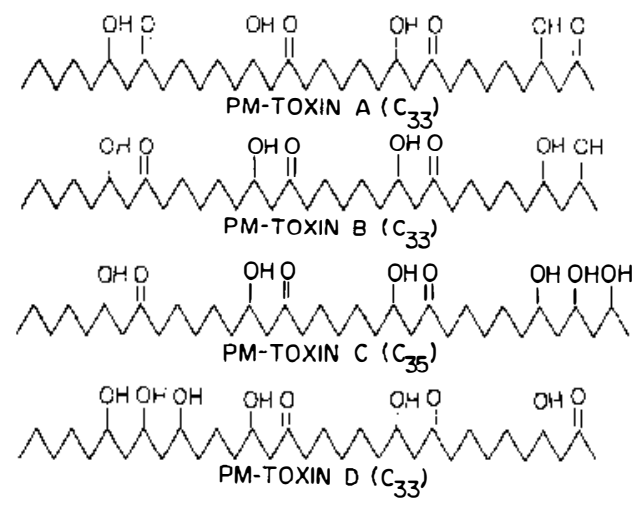

Figure 5 The chemical structures of toxin from Phyllosticta maydis specifically affecting corn with Texas male sterile cytoplasm (26).

(Figure 6). Thus, it appears that a minimum of four, but perhaps three, precisely-spaced sets of two $ß$ oxygen functions are required for specificity and high toxicity in causing damage to corn with Texas male sterile cytoplasm.

\section{Host Components}

The precise interaction of most HST with host components is as yet unknown. Because (with some exceptions) HST cause a rapid leakage of solutes from sensitive cells, it has been generally believed that interaction with plasma membranes occurs (50). However, mitochondria (91) are likely targets of Hmt-toxin in vivo but may not be the only organelles to be affected $(22,118)$. The results described above for HMT and PM-toxins are suggestive of a distinct molecular architecture in sensitive mitochondria. There is evidence for the presence in sensitive mitochrondria of a polypeptide absent in mitochrondria obtained from resistant corn (44). However, direct evidence that this polypeptide interacts with Hmt-toxin is lacking. The findings with HS-toxin and its protective analogs also are suggestive of a unique host toxin receptor capable of interacting with toxin. Although a specific binding protein in membranes of susceptible sugar cane has been claimed for HS-toxin (117), the data supporting the claim are not experimentally satisfactory (24). Attempts to duplicate these results by Lesney et al (80) have not been successful.

Unlike nearly all other HST, AAL-toxin (Figure 4) does not cause ion leakage, but its necrotic effects can be prevented by L-aspartate and by orotate, suggesting that aspartate carbonoyl-transferase (ACTase), a key enzyme in arginine and pyrimidine biosynthesis, might be affected. ACTase [an allosteric enzyme modulated by the feedback inhibitor uridine monophosphate (UMP)] was isolated by McFarland and Gilchrist [summarized in (52)] from genetically homozygous susceptible or resistant tomato. The enzymes from the two culti- 


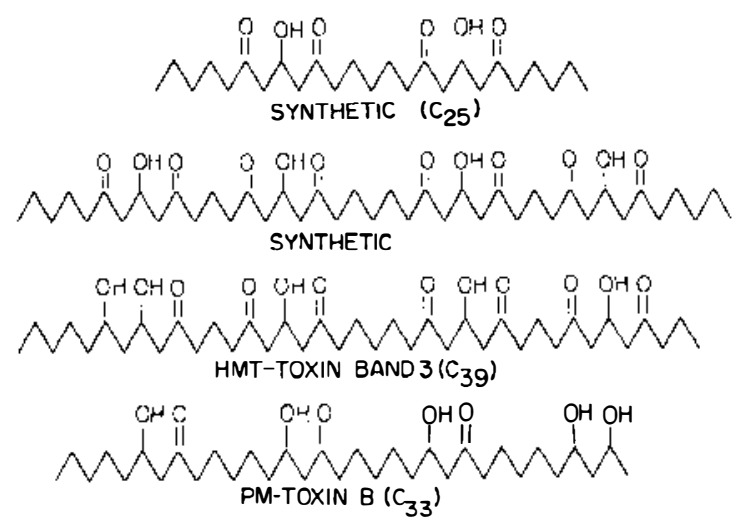

Figure 6 Comparison of chemical structures of a component of PM- and HmT-toxins, plus two synthetic analogs of the latter. Note the positioning of oxygen functions of each. See text for details.

vars appeared to have identical physical and kinetic properties in the absence of AAL-toxin. Kinetic analysis (52) revealed that, in the presence of UMP, AAL-toxin acted as a potent synergist for regulatory inhibition by UMP, particularly with the ACTase from the susceptible genotype. It is postulated that, in vivo, the synergist effect would result in nearly complete loss of ACTase activity in susceptible plants, even at UMP concentrations that by themselves would be non-inhibitory (52). This view of the mode of action of HST is a radical departure from earlier views that focused on membrane functions rather than cytosolic metabolism.

\section{Comments}

In evaluating the data obtained with HST, it can be argued that they represent special cases of a specific disease reaction and therefore of recognition. It is also true, however, that pathogenesis in these diseases does not differ markedly, if at all, from pathogenesis in diseases for which recognition is postulated to require surface macromolecules. In common with many diseases, host resistance apparently is determined by single genes that most often are dominant. Further, production of HST is inherited as a single trait in the few cases for which sound genetic data are available. With $H$. maydis race $\mathrm{T}$, the single gene control of toxin production studied by Tegtmeier et al (120) appears to be absolute (no detectable toxin) and is inherited as a dominant or co-dominant genetic factor (79), although the gene functions as a gene for virulence rather than avirulence.

In instances of dominant genes for host resistance in diseases involving HST, there are several possible biochemical explanations for resistance that need to be investigated because they have direct bearing on the meaning of dominance or recessiveness in models of host-pathogen interaction. The simplest explana- 
tion is that susceptible hosts have a gene product with which toxin interacts, while resistant hosts lack such a product. Sound experimental evidence for this still is lacking.

Alternatively, resistance might result from host destruction or modification of HST, while susceptible tissues lack such ability. This implies an active gene product for resistance rather than the absence of a product. The reverse may occur; chemical activation of HST in susceptible hosts may be accomplished by an active gene product. Similar reasoning can be applied to several other potential mechanisms, i.e. ability or inability to transport HST to sensitive cellular sites. Finally, Wheeler's self-repair $(24,135,136)$ hypothesis should be considered in examining these problems. Wheeler suggests that both resistant and susceptible hosts possess sites of equal sensitivity, but resistant hosts have a capacity for metabolic recovery from an initial biochemical lesion.

These hypotheses are a reminder that we have insufficient biochemical evidence to attempt assessment of the significance of dominant or recessive inheritance of disease reaction with HST. All scenarios are biochemically feasible, but it has not been possible to test the alternatives experimentally until recently, when knowledge of the structure was obtained. Likewise, it is unclear what single gene control of toxin production in the pathogen signifies. An examination of the structures of HST indicates that they are typical products of secondary metabolism and thus require several distinct enzymatic steps. It is possible that a terminal step in synthesis may require a unique enzyme that would be coded by a single gene, biologically identified as a virulence gene. Much of our thinking about these problems is conditioned by the notion that HST have been produced in very small amounts and perhaps represent mere aberrants of fungal metabolism. This is not the case for HMT-toxin, which is recoverable to the extent of $2-3 \%$ of the mycelial dry weight (120) and thus is not a minor metabolite. Likewise, it is not unusual (S. Him, H. W. Knoche, unpublished data) to obtain 30-50 mg of HC-toxin in pure form from a liter of culture. To understand genetic control of virulence factors will require a knowledge of biosynthetic pathways, a task for the future.

\section{DISCUSSION}

The available literature indicates clearly that macromolecules obtained from microbial cell walls or membranes are capable of effecting biochemical responses in plant cells similar to the responses found in incompatible disease reactions. There is only limited evidence, with little or no independent verification, that such molecules serve as a means of special recognition between hosts and their pathogens in determining incompatibility. Cell surface or wall molecules of pathogens may function in adherence to host cells, but adherence per se has not yet been proven to trigger either compatible or incompatible host 
responses. Even if the most optimistic reports are fully accepted, the results obtained with wall-derived inducers of incompatible responses contain inherent paradoxes. The surfaces of Phytophthora megasperma var. glycinea appear to possess both specific (69) and non-specific (2) information for phytoalexin accumulation. Galactosamine polymers such as chitin or chitosan (60) undoubtedly are present in both compatible and incompatible fungi. Without major qualification, it appears that any wall macromolecules containing specific information relating to resistance must normally operate against a backdrop of non-specific "noise" generated by non-specific wall components that could be appreciable in terms of phytoalexin accumulation. Either the non-specific inducers are "masked" in native walls or the amounts are much less than the amounts (or the accessibility) of the specific inducers. An alternative is that non-specific wall components activate a general resistance response that is suppressed by other race-specific wall components as suggested by the work of Doke and colleagues (33). If so, compatibility, not incompatibility $(1,40,68)$, would seem to be the unique aspect under genetic control by the host and the pathogen. Underlying all such hypotheses is the assumption that the observed responses (phytoalexin accumulation, hypersensitive reaction, etc) constitute a true resistance mechanism and are not merely symptoms of stress with no functional role in disease reaction (21).

On the other hand, a reasonable case can be constructed for low molecular weight compounds as devices for recognition in some diseases. HST fulfill the basic requirements for recognition. They cause very rapid initial responses that determine the subsequent outcome of host reaction. In certain cases (HV- and AM-toxin), evidence has been presented $(101,138)$ that HST are prerequisites for disease to occur. Toxin-less strains do not develop on host tissue and the inoculum of pathogenic strains contains detectable toxin. In other cases (Hmtand HS-toxin), initial colonization of both resistant and susceptible host tissue occurs; the toxin functions to increase host damage and presumably permits much more extensive pathogen colonization in susceptible plants. As Wheeler has pointed out (136), much additional work is required to fully assess the role of HST in pathogenesis.

In common with other models of recognition, it has been generally believed that HST interacts with a constitutive gene product of the cell surface, probably a membrane protein as suggested for HV-toxin (56) and the toxin of Periconia circinata (49). However, the recent work by Wolpert \& Dunkle (137) indicates that the latter toxin acts in the cytoplasm and causes alteration of gene expression in susceptible sorghum tissues. Several proteins, but particularly a $16 \mathrm{~K}$ dalton protein apparently with four subunits, were selectively synthesized within six hours after toxin treatment of susceptible sorghum roots. The role of the proteins is unknown, but since protection from toxin was afforded by cycloheximide (137), they may be responsible for the development of cellular 
damage. The effects of AAL-toxin on ACT-ase (52) and Hmt-toxin on mitochrondria (97) show that HST are not limited to interaction at cell surfaces. Obviously, these targets are a normal part of cellular metabolism, not unique proteins designed only for the recognition of pathogens, as most speculation about recognition implies.

It is obviously unwise to generalize about mechanisms of recognition in plant disease from the relatively few known examples of HST. It can not be overemphasized, however, that work on toxins is in its infancy. The establishment of HST as factors in certain diseases has been dependent on techniques weighted toward isolation of a single chemical entity possessing both high specificity and high toxicity. By analogy with toxin affecting animals, low molecular weight non-toxic metabolites conferring specificity may act synergistically with non-specific toxins, for example, by altering uptake by host cells. Systematic exploration of such possibilities lies in the future.

In any event, the existence of HST raises the question of whether recognition in plant disease requires cell surface mechanisms such as those currently in vogue for animal cells. Animal cells are not encumbered by a cell wall. The presence of the wall around plant cells has limited knowledge about the composition and asymmetry of the plant plasma membrane. Because there is a rigid wall, the membrane may be different organizationally from animal cell membranes and not designed to serve primarily as an information-transducing organelle, or at least not to the same extent. The existence of plasmodesmata in plants provides a device, perhaps a superior one, for cell-to-cell communication. In keeping with the current concepts of recognition in animal systems, it is interesting that the majority of animal messenger hormones are polypeptides, while there are no known polypeptides hormones of plants. As with toxins, plant hormones are diverse in structure and of low molecular weight. Further, evidence for hormone binding by plants organelles has been difficult to obtain. The surface processes observed in the complex immune response of animals, which require several specialized cells, may not be appropriate as a response to infection by a totipotent plant cell.

Cell-surface recognition may be appropriate for plant disease, however, if it conforms with the biological patterns of diseases for which it is invoked. Current models generally envision a single yes-or-no, all-or-none signal transduction; either compatibility or incompatibility is the result of the message. Although useful for building theoretical models, there are several problems in general application.

To illustrate the difficulties, the events underlying compatibility and incompatibility are quite different for biotrophic (rusts, mildews) and necrogenic (Septoria, Helminothosporium) disease of wheat leaves. For biotrophic diseases, compatibility is a useful term to describe infection of susceptible hosts, 
but obviously the events are different than with a necrotic leaf spot where "compatibility" results in more tissue damage than with incompatibility. If resistance is the unique aspect of host-pathogen interactions $(40,41)$, it seems necessary that at least two sorts of sensing components, one for biorophic and one for necrogenic responses, would be necessary on the cell surface. The genetic basis of resistance for each necrogenic or biotrophic disease is different. When one considers the number of such diseases on wheat, and especially the pathogenic strains within a single disease, the packaging and maintenance of all the necessary information at the host interface is a considerable task, although not impossible. Similar considerations (133) apply to molecules, not necessarily at the surface, but uniquely fabricated for incompatibility such as with the dimer hypothesis or suppressor molecules.

A second complication is that plant disease reaction most frequently is not a yes-or-no situation. As noted earlier (21), there is a dearth of requisite quantitative data for necrogenic diseases that relate pathogen growth to biochemical processes at various stages in resistant and susceptible hosts. For biotrophic diseases, a considerable literature indicates that the initial histological events are similar for extended periods, up to 72 hours with rust fungi $(91,115)$. Further, even with incompatible reactions, growth can continue for a number of days. These facts suggest that surface recognition, if it occurs in these diseases, develops during pathogenesis and does not involve a constitutive signal.

Additionally, the variability in plant disease reaction, even in instances of single gene control, must be accommodated in any theory of recognition. The influence of environmental variables on disease development can be rationalized by assuming that control by environment occurs during subsequent cytoplasmic events, not during the initial signal at the surface. If so, is surface signal transduction of prime importance then? The explanation is difficult to apply in instances where environmentally caused variability in disease reaction is associated only with certain genes for resistance, such as the temperaturesensitive Sr6 allele for stem rust resistance (18). As a consequence of a study of the role of environment on the infection of soybean by Phytophthora megasperma f. sp. glycinea, Ward \& Buzzel (132) were moved to note: "The assumption that recognition is for incompatibility would lead to the conceptually difficult conclusion that dark grown plants specifically cause these races to lose their ability to produce the appropriate race specific molecule, that light restores it and that elevated temperature again destroys it, provided also that the plants are wounded."

The most logical systems for elucidating the chemical basis of recognition is with biotrophic diseases, particularly of cereals, which exhibit high specificity in host-pathogen interaction. Preliminary attempts to detect single polypeptides corresponding to specific genes for resistance in the host (46) or avirulence 
genes of races of rust (65) have not been successful. The problems may lie in a lack of resolution with techniques available, although the basic assumptions, derived from theoretical genetic models, may be questioned.

Unfortunately, the theoretical genetic models deal in disease reaction in terms of absolute values of R (resistance) or S (susceptibility), but the symbols do not acknowledge the range of phenotypes encountered in each reaction class. In stem rust of wheat, for example, resistant reactions consist of four classes: 0 (immune), 1, and 2. Biologically speaking, there is a larger gap between the immune reaction and infection type 2 of resistance than between resistance (infection type 2) and susceptibility (infection type 3 ). For genetic purposes, these considerations perhaps are minor, but in biochemical studies they cannot be ignored. Although grouped into a single reaction class $(R)$, there obviously are significant biochemical differences between an immune reaction and an infection type 2. To illustrate the importance of these differences for studies of recognition, let us assume that macromolecules have been obtained from host or pathogen combinations characterized by an infection type 2 but are capable of inducing only an immune reaction. Despite the fact that a resistance response is induced, it would lack the requisite biological specificity to be meaningful as a device for recognition.

In short, a basic problem with current genetic and recognition models is that they are static, without the known plasticity of natural disease reaction. They do not acknowledge the existing phenotypic variability nor do they satisfactorily account for the continuum of host-pathogen reaction types observed in many diseases. The current models are also cumbersome in that it seems necessary to postulate the existence of a basic host-pathogen compatibility upon which is superimposed a set of independent genetic factors for resistance to individual races or strains $(40,41)$ or a set of additional genes and products for suppression of a general host response.

For me, two sets of genetic information seem redundant. High specificity can be achieved with biological economy if genes for basic compatibility produce enzymes that are regulatory or allosteric. At critical stages of pathogen development (recognized as infection types), an additional biochemical process is activated to permit continued development of the pathogen and of disease (18). With regulatory enzymes, activation could entail low molecular weight effectors from the pathogen. Cessation of development at any stage (manifestation of resistance) could result from: (a) the presence of a variant or a host gene product that can not be regulated, or $(b)$ the lack of production of appropriate effectors from the pathogen. A similar model can be constructed if an active mechanism for resistance determines the outcome of infection.

Whether such possibilities are consistent with the dominant or recessive character of inheritance is a moot point at this stage in our biochemical understanding of gene expression in higher plants, particularly for disease 
reaction. There are several observations that indicate expression of genes for disease resistance may be complex. A recent study by Knott (70), for example, indicates that $\mathrm{Sr} 6$ allele, effective against races 56 and 15B-1 of wheat stem rust, when introduced into four susceptible wheat cultivars is inherited $(a)$ as a dominant gene against both races in two of the crosses, $(b)$ as dominant against $15 \mathrm{~B}-1$ and recessive against race 56 in the third cross, and $(c)$ as a recessive against both races in the fourth cross. Similar results have been obtained with genes for leaf rust resistance in wheat (38). It is also difficult to explain the so-called mesothetic reaction in rust disease, in which a single leaf will support the entire range of compatible and incompatible infection types.

Regulatory enzymes suggest one possible way by which normal metabolism can be altered to account for disease reaction. They are macromolecules normally present in higher plant cells and impose no extra load on the existing genetic or metabolic machinery. Only minor modification of an effector binding site, perhaps the substitution of a single amino acid residue, can alter their regulatory capacity but not necessarily their innate capacity to carry out important functional reactions in normal uninfected cells. This has the important consequence that only minor changes in DNA sequences can lead to large effects on disease reaction. Further, the nature of the altered DNA sequences need not necessarily be the same for individual cultivars.

\section{SUMMARY}

Evidence that surface macromolecules mediate specific recognition by signal transduction at host-pathogen interfaces in plant disease is as yet limited. Most investigations of the phenomenon have been designed with the assumption that incompatibility, and not compatibility, is the disease reaction that requires specific recognition. On the other hand, chemically defined, low molecular weight pathogen products (host-selective toxins) have been identified that fulfill the biological and chemical expectations for specific recognition. In some instances, they have cytoplasmic targets and affect host metabolism without cell surface signal transduction. Further, disease reaction in these cases is that of susceptibility, not resistance.

There is a question, therefore, of whether some of the current widely-held assumptions about the basic events in resistance, and their genetic control, are valid. Rather than the static, all-or-none models for recognition and disease resistance that now are in vogue, it may be more germane to examine models in which metabolic regulation, for compatibility as well as for incompatibility, determines the outcome of microbial infection of higher plants. Specific pathogen effectors, either negative (i.e. toxins) or positive (i.e. growth regulants), acting to alter the rates of basic metabolism controlled by host geneproducts (enzymes) would be consistent with the inherent variation of disease 
reaction due to environment. Such models would also account for the range of reaction encountered within broad classes of compatibility or incompatibility.

\section{Literature Cited}

1. Albersheim, P., Anderson-Prouty, A. J. 1975. Carbohydrates, proteins, cell surfaces and biochemistry of pathogenesis. Ann. Rev. Plant Physiol. 26:31-52

2. Ayers, A. R., Ebel, J., Finelli, F., Berger, N., Albersheim, P. 1976. Host pathogen interactions. IX: Quantitive assays of elicitor activity and characterization of the elicitor present in the extracellular medium of cultures of Phytophthora megasperma var. sojae. Plant Physiol. 57:751-59

3. Ayers, A. R., Ebel, J., Valent, B., Albersheim, P. 1976. Host pathogen interactions. X: Fractionation and biological activity of an elicitor isolated from the mycelial walls of Phytophthora megasperma var. sojae. Plant Physiol. 57: 760-.65

4. Ayers, A. R., Valent, B., Ebel, J., Albersheim, P. 1976. Host pathogen interactions. XI: Composition and structure of wall-released elicitor fractions. Plant Physiol. 57:766--74

5. Bauer, W. D. 1981. Infection of legumes by Rhizobia. Ann. Rev. Plant Physiol. 32:407-84

6. Bauer, W. D. 1982. The initiation of infections in legumes by Rhizobia. In Plant Infection. The Physiological and Biochemical Basis, ed. Y. Asadea, W. R. Bushnell, S. Ouchi, C. P. Vance, pp. 61-78. Tokyo: Jpn. Sci. Soc. Press

7. Bohlool, B. B., Schmidt, E. L. 1974. Lectins: A possible basis for specificity in the Rhizobium-legume nodule symbiosis. Science 185:269-71

8. Bostock, R. M., Laine, R. M. Kuć, J. 1983. Factors affecting the elicitation of sesquiterperoid phytoalexin accumulation by eicosapentraenoic and arachidonic acids in potato. Plant Physiol. 70: 1417-24

9. Bottini, A. T., Bowen, J. R., Gilchrist, D. G. 1981. Phytotoxins. II: Characteristics of phytotoxic fractions of Alternaria alternata f. sp. lycopersici. Tetrahedron Lett. 22:2723-26

10. Bruegger, B. B., Keen, N. T. 1979. Specific elicitors of glyceollin accumulation in the Pseudomonas glycinea-soybean host-parasite system. Physiol. Plant Pathol. 15:43-51

11. Bumet, F. M. 1971. "Self-recognition" in colonial marine forms and flowering plants in relation to the evolution of immunity. Nature 232:230-35

12. Bumet, F. M. 1976. The evolution of receptors and recognition in the immune system. In Receptors and Recognition, Ser. $A$, ed. P. Caurrecasas, M. F. Greaves 1:35-38. London: Chapman \& Hall

13. Bushnell, W. R. 1979. The nature of basic compatibility: Comparisons between pistil-pollen and host-parasite interaction. In Recognition and Specificity in Plant Host-Parasite Interactions, ed. J. M. Daly, I. Uritani, pp. 211-29. Tokyo: Jpn. Sci. Soc. Press

14. Callow, J. A. 1977. Recognition, resistance, and role of plant lectins in hostparasite interactions. Adv. Bot. Res. 4:149

15. Ciuffetti, L. M., Pope, M. R., Dunkle, L. D., Daly, J. M., Knoche, H. W. 1983. Isolation and structure of an inactive product derived from the host-specific toxin produced by Helminthosporium carbonum. Biochemistry 22:350710

16. Clarke, A. E., Knox, R. B. 1978. Cell recognition in flowering plants. Quart. Rev. Biol. 53:3-28

17. Closse, A., Huguenin, R. 1974. Isolierung and Serukturaufklärung von Chlamydocin. Helv. Chim. Acta 57:53345

18. Daly, J. M. 1972. The use of nearisogenic lines in biochemical studies of the resistance of wheat to stem rust. Phytopathology 62:392--400

19. Daly, J. M. 1976. Some aspects of hostpathogen interactions. In Physiological Plant Pathology, ed. R. Heitefuss, P. H. Williams, pp. 27-50. Berlin/Heidelberg/ New York: Springer-Verlag

20. Daly, J. M. 1976. Specific interactions involving hormonal and other changes. In Specificity in Plant Diseases, ed. R. K. S. Wood, A. Graniti, pp. 151-67. New York: Plenum

21. Daly, J. M. 1983. Current concepts of disease resistance in plants. In Challenging Problems in Plant Health, ed. T. Kommendahl, P. M. Williams, pp. 31123. St. Paul: Am. Phytopathol. Soc.

22. Daly, J. M., Barna, B. 1980. A differential effect of Race $T$ toxin on dark and photosynthetic $\mathrm{CO}_{2}$ fixation by thin leaf 
slices from susceptible corn. Plant Physiol. 66:580-83

23. Daly, J. M., Deverall, B. J. Toxins and Plant Pathogenesis. Sydney, Australia: Academic. $181 \mathrm{pp}$.

24. Daly, J. M., Knoche, H. W. 1982. The chemistry and biology of pathotoxins exhibiting host-selectivity. Adv. Plant Pathol. 1:83-138

25. Daly, J. M., Kono, Y., Suzuki, Y., Knoche, H. W. 1983. Biological activities and structures of host-selective pathotoxins. In IUPAC Pesticide Chemistry. Human Welfare and the Environment, ed. J. Miyamoto, pp. 11-20. Oxford: Pergamon

26. Danko, S. J., Kono, Y., Daly, J. M., Suzuki, Y., Takeuchi, S., McCrery, D. A. 1984. Structure and biological activity of a host-specific toxin produced by the fungal corn pathogen Phyllosticta maydis. Biochemistry 23:759-66

27. Day, P. 1974. Genetics of Host-Parasite Interaction. San Francisco: W. H. Freeman. 239 pp.

28. Dazzo, F. B. 1980. Adsorption of microorganism to roots and other plant surfaces. In Adsorption of Microorganisms to Surfaces, ed. G. Bitton, K. C. Marshall, pp. 253-316. New York: Wiley

29. Dazzo, F. B., Yanke, W., Brill, W. J. 1978. Trifoliin: A Rhizobium recognition protein from white clover. Biochem. Biophys. Acta 539:276-86

30. Des jardins, A. E., Ross, L. M., Spellman, M. W., Darvill, A. G., Albersheim, P. 1982. Host pathogen interactions. XX: Biological variation in the protection of soybeans from infection by Phytophthora megasperma f. sp. gly. cinea. Plant Physiol. 69:1046-50

31. DeWit, P. J. G., Spikman, G. 1982. Evidence for the occurrence of race and cultivar-specific elicitors of necrosis in intercellular fluids of compatible interactions of Cladosporium fulvum and tomato. Physiol. Plant Pathol. 21:1-11

32. Doke, N. 1975. Prevention of the hypersensitive reaction of potato cells to infection with an incompatible race of Phytophthora infestans by constituents of the zoospores. Physiol. Plant Pathol. 7:1-7

33. Doke, N., Garas, N. A., Kuć, J. 1979. Partial characterization and aspects of the mode of action of a hypersensitivity factor (HIF) isolated from Phytophthora infestans. Physiol. Plant Pathol. 15:12740

34. Doke, N., Tomiyama, K. 1980. Suppression of the hypersensitive response of potato tuber protoplasts to hyphal wall components by water soluble glucans isolated from Phytophthora infestans. Physiol. Plant Pathol. 16:177-86

35. Dow, J. M., Callow, J. A. 1979. Leakage of electrolytes from isolated cell mesophyll cells of tomato induced by glycopeptides from culture filtrates of Falvia Fulva (Cooke) Ciferri (syn. Cladosporium fulvum). Physiol. Plant Pathol. 15:27-34

36. Durbin, R. D., ed. 1981. Toxins in Plant Disease. New York: Academic

37. Duvick, J., Daly, J. M., Kratky, Z., Macko, V., Acklin, W., Arigoni, D. 1984. Biological activity of the isomeric forms of Helminthosporium saccharri toxin and of homologs produced in culture. Plant Physiol. 74:117-22

37a. J. Duvick, J. M. Daly, Z. Kratby, V. Macko, W. Acklin, D. Avigoni, unpublished data

38. Dyck, P. L., Samborski, D. J. 1968 Genetics of resistance to leaf rust in the common wheat varieties Webster, Loris, Brenit, Carma, Malakof and Centenario. Can. J. Genet. Cytol. 10:7-17

39. East, E. M. 1929. Self-sterility. Bibliogr. Genet. 5:331-70

40. Ellingboe, A. H. 1976. Genetics of hostparasite interactions. See Ref. 19, pp. 761-78

41. Ellingboe, A. H. 1979. Inheritance of specificity: the gene-for-gcne hypothesis. See Ref. 13, pp. 3-17

42. Falcone, G., Nickerson, W. J. 1956. Cell-wall mannan-protein of baker's yeast. Science 124:272-73

43. Flor, H. H. 1955. Host-parasite interaction in flax rust-Its genetics and other implications. Phytopathology 45:680-85

44. Forde, B. G., Oliver, R. J. C., Leaver, L. J. 1978. Variation in mitochondrial translation products associated with male-sterile cytoplasm in maize. Proc. Natl. Acad. Sci. USA 75:3841-45

45. Frazier, W., Glaser, L. 1979. Surface components and cell recognition. Ann. Rev. Biochem. 48:491-523

46. Gabriel, D. W., Ellingboe, A. H. 1982. High resolution two-dimensional electrophoresis of protein from congenic wheat lines differing by single resistance genes. Physiol. Plant Pathol. 20:34957

47. Gade, W., Jack, M. A., Dahl, J. B., Schmidt, E. L., Wold, F. 1981. The isolation and characterization of a root lectin from soybean (Glycine max L.) $J$. Biol. Chem. 256:12905-910

48. Garas, N. A., Doke, N., Kuć, J. 1979. Suppression of the hypersensitive action in potato tubers by mycelial components 
from Phytophthora infestans. Physiol. Plant Pathol. 15:117-28

49. Gardner, J. M., Mansour, I. S., Scheffer, R. P. 1972. Effects of the hostspecific toxin of Periconia circinata on some properties of sorghum plasma membranes. Physiol. Plant Pathol. 2: 197-206

50. Gardner, J. M., Scheffer, R. P. 1973. Effects of cycloheximide and sulfhydrylbinding compounds on sensitivity of oat tissues to Helminthosporium victoriae toxin. Physiol. Plant Pathol. 3:147-57

51. Gibson, D. M., Stack, S., Krell, K., House, J. 1982. A comparison of soybean agglutinin in cultivars resistant and susceptible to Phytophthora magasperma var. sojae (Race 1). Plant Physiol. 70:560-66

52. Gilchrist, D. G. 1983. Molecular modes of action. See Ref. 23, pp. 81-136

53. Gilchrist, D. G., Grogan, R. G. 1976. The production and nature of a hostspecific toxin from Alternaria alternata f. sp. lycopersici. Phytopathology 66: 165-71

54. Goodman, R. N., Huang, Y-Y., White, J. A. 1976. Ultrastructural evidence for immobilization of an incompatible bacterium, Pseudomonus pisi, in tobacco leaf tissue. Phytopathology 66:754-64

55. Graham, T. L., Sequeira, L., Huang, T. R. 1977. Bacterial lipopolysaccharides as inducers of disease resistance in tobacco. Appl. Environ. Microbiol. 34:42432

56. Gross, M. L., McCrery, D., Crow, F., Tomer, K. B., Pope, et al. 1982. The structure of the toxin from Helminthosporium carbonum. Tetrahedron Lett. 23:5381-84

57. Hadwiger, L. A., Beckman, J. M. 1980. Chitosan as a component of peaFusarium solani interactions. Plant Physiol. 66:205-11

58. Hadwiger, L. A., Beckman, J. M., Adams, M. J. 1981. Localization of fungal components in the pea-Fusarium interaction detected immunochemically with anti-chitosan and anti-fungal cell wall antisera. Plant Physiol. 67:170-75

59. Hadwiger, L. A., Line, R. F. 1981. Hexosamine accumulations are associated with the terminated growth of Puccinia striformis on wheat isolines. Physiol. Plant Pathol. 19:240-55

60. Hadwiger, L. A., Loschke, D. C. 1982. Molecular communication in host parasite interactions: Hexosamine polymers (chitosan) as regulator compounds in race-specific and other interactions. Phytopathology 71:756-62

61. Hadwiger, L. A., Loschke, D. C., Teas- dale, J. 1977. An Evaluation of pea histones as disease resistance factors. Phytopathology 67:755-58

62. Hadwiger, L. A., Wagoner, W. 1983. Electrophoretic patterns of pea and Fusarium solani proteins synthesized in vitro or in vivo which characterized the compatible and incompatible interactions. Physiol. Plant Pathol. 23:153-62

63. Hildebrand, D. C., Alosi, M. C., Schroth, M. N. 1980. Physical entrapment of pseudomonads in bean leaves by films formed at air-water interfaces. Phytopathology 70:98-109

64. Hirota, A. Suzuki, A., Aizawa, K., Tamura, S. 1973. Structure at CYI-2, a novel cyclotetra peptide from $C$ ylindrocladium scoparium. Agric. Biol. Chem. 37:955-56

65. Howes, N. K., Kim, W. K., Rohringer, R. 1982. Detergent-soluble polypeptides extracted from uredospores of four physiologic races of Puccina graminis tritici. Physiol. Plant Pathol. 21:361-66

66. Kawakita, K., Kojima, M. 1983. The isolation and properties of a factor in taro tuber that agglutinates spores of Ceratocystis fimbriata, black rot fungus. Plant Cell Physiol. 24:41-49

67. Keen, N. T. 1975. Specific elicitors of plant phytoalexin production: Determinants of race specificity in pathogens. Science 187:74-75

68. Keen, N. T. 1982. Phytoalexins-Progress in regulation of their accumulation gene-for-gene interactions. See Ref. 6, pp. 281-300

69. Keen, N. T., Legrand, M. 1980. Surface glycoproteins: Evidence that they may function as the race specific phytoalexin elicitors of Phytophothora megasperma f. sp. glycinea. Physiol. Plant Pathol. 17:175-92

70. Knott, D. R. 1981. The effects of genotype and temperature on the resistance to Puccinia graminis tritici controlled by the gene Sr6 in Triticum aestivum. Can. J. Genet. Cytol. 23:183-90

71. Kojima, M., Kawakita, K., Uritani, I. 1982. Studies on a factor in sweet potato root which agglutinates spores of Ceratocystis fimbriata, black rot fungus. Plant Physiol. 69:474-78

72. Kojima, M., Uritani, I. 1974. The possible involvement of a spore agglutinating factor(s) in various plants in establishing host specificity by various strains of black rot fungus, Ceratocystis fimbriata. Plant Cell Physiol. 8:97-111

73. Kojima, M., Uritani, I. 1978. Isolation and characterization of factors in sweet potatoroot which agglutinate germinated spores of Ceratocystis fimbriata, black 
rot fungus. Plant Physiol. 62:751-53

74. Kojima, M., Uritani, I. 1978. Studies on factors in sweet potato root which induce spore germination of Ceratocystis fimbriata. Plant Cell Physiol. 19:91-97

75. Kono, Y., Daly, J. M. 1979. Characterization of the host-specific pathotoxin produced by Helminthosporium maydis race $\mathrm{T}$, affecting com with Texas male stcrile cytoplasm. Bioorg. Chem. 8:39197

76. Kono, Y., Knoche, H. W., Daly, J. M. 1981. Structure: Fungal host-specific. See Ref. 36, pp. 221-51

77. Leach, J. E., Cantrell, M. A., Sequeira, L. 1982. A hydroxyproline-rich bacterial agglutinin from potato: Its localization by immune fluorescence. Physiol. Plant Pathol. 21:319-25

78. Leach, J. E., Cantrell, M. A., Sequeira, L. 1982. Agglutinin from potato: Extraction, purification, and characterization. Plant Physiol. 70:1353-58

79. Leach, J., Tegtmeier, K. J., Daly, J. M., Yoder, O. C. 1982. Dominance at the Toxl locus controlling T-toxin production by Cochliobolus Heterostrophus. Physiol. Plant. Pathol. 21:327-34

80. Lesney, M. A., Livingston, R. S., Scheffer, R. P. 1982. Effects of toxin from Helminthosporium sacchari on nongreen tissucs and a reexamination of toxin binding. Phytopathology 72:844-49

81. Lewis, D. 1965. A protein dimer hypothesis of incompatibility. Genet. Today 3:657-63

82. Liesch, J. M., Sweeley, C. C., Staffeld, G. D., Anderson, M. S., Weber, D. J., Scheffer, R. P. 1982. Structure of HCtoxin, a cyclic polypeptide from Helminthosporium carbonum. Tetrahedron Lett. $38: 45-48$

83. Lippincott, B. B., Whatley, M. H., Lippincott, J. A. 1977. Tumor induction by Agrobacterium involves attachment of the bacterium to a site on the host cell wall. Plant Physiol. 59:388-90

84. Lippincott, J. A., Lippincott, B. B. 1979. Cell walls of crown-gall tumors and embryonic plant tissues lack Agrobacterium adherence sites. Science 199:1075-77

85. Livingston, R. S., Scheffer, R. P. 1981. Fungal products chemically related to Helminthosporium saccari toxin protect sugar cane tissues from the toxin. Phytopathology 71:891 (Abstr.)

86. Livingston, R. S., Scheffer, R. P. 1981. Isolation and characterization of hostselective toxin from Helminthosporium sacchari. J. Biol. Chem. 256:1705-10

87. Livingston, R. S., Scheffer, R. P. 1983. Enzymatic conversion of Helmintho- sporium sacchari toxin to toxoids by Bgalacto-furanosidase from Helminthosporium. Plant Physiol. 72:530-34

88. Macko, V. 1983. Structural aspects of toxins. See Ref. 23, pp. 41-80

89. Macko, V., Acklin, W., Hildenbrand, D., Weibel, F., Arigoni, D. 1983. Structure of three isomeric host-specific toxins from Helminthosporium sacchari. Experientia 39:343-47

90. Macko, V., Goodfriend, K., Wachs, T. Renwick, J. A., Acklin, W., Arigoni, D. 1981. Characterization of the hostspecific toxins produced by Helminthosporium sacchari, the causal organism of eyespot disease of sugarcane. Experientia 37:923-24

91. Matthysse, A. G., Gurlitz, R. H. G. 1982. Plant cell range for attachment of Agrobacterium tumefaciens to tissue culture cells. Physiol. Plant Pathol. 21:38187

92. Matthysse, A. G., Holmes, K. V., Gurlitz, R. H. G. 1981. Elaboration of cellulosefilrils by Agrobacterium tumefaciens during attachment to carrot cells. J. Bacteriol. 145:583-95

93. Matthysse, A. G., Holmes, K. V., Gurlitz, R. H. G. 1982. Binding of Agrobacterium tumefaciens to carrot protoplasts. Physiol. Plant. Pathol. 20:27-33

94. Mayama, S., Daly, J. M., Rehfeld, D. W. 1975. A comparison of the development of Puccinia graminis tritici in resistant and susceptible hosts based on glucosamine content. Physiol. Plant Pathol. 7:243-57

95. Mayama, S., Daly, J. M., Rehfeld, D. W., Daly, C. R. 1975. Hypersensitive response of near-isogenic wheat carrying the temperature-sensitive Sr6 allele for resistance to stem rust. Physiol. Plant Pathol. 7:35-47

96. Mellon, J. E., Helgeson, J. P. 1982. Interaction of hydroxyproline-rich glycoprotein from tobacco callus with potential pathogens. Plant Physiol. 70:4015

97. Miller, R., Koeppe, D. 1971. Southern com leaf blight: Suspectible and resistant mitochondria. Science 173:67-69

98. Moss, J., Vaughn, M. 1979. Activation of adenylate cyclase by cholcragen. Ann. Rev. Biochem. 48:581-600

99. Mulcahy, D. L., Mulcahy, G. B. 1983. Gametophytic self-incompatibility reexamined. Science 220:1247-51

100. Nichols, E. J., Beckman, J. M., Hadwiger, L. A. 1981. Gycosidic enzyme activity in pea tissue and pea-Fusarium interactions. Plant Physiol. 66:199-204

101. Nishimura, S., Kohmoto, K., Otani, H. 1979. The role of host-specific toxins in 
saprophytic pathogens. See Ref. 13, pp. 133-46

102. Person, C. 1959. Gene-for-gene relationships in host-parasite systems. Can. J. Bot. 37:1101-30

103. Pope, M. R., Ciuffetti, L. M., Knoche, H. W., McCrery, D., Daly, J. M., Dunkle, L. D. 1983. Structure of the hostspecific toxin produced by Helminthosporium carbonum. Biochemistry 22: 3502-6

104. Pueppke, S. G., Benny, U. K. 1983. Agrobacterium tumourigenesis in potato: Effect of added Agrobacterium lipopolysaccharides and the degree of methylation of added plant galacturonans. Physiol. Plant Pathol. 23:440-45

105. Pueppke, S. G., Hymowitz, T. 1982. Screening of the genus Glycine subgenus Glycine for the 120,000 dalton seed lectin. Crop Sci. 22:558-60

106. Pueppke, S. G., Kluepfel, D. A., Anand, V. K. 1982. Interactions of Agrobacterium with potato lectin and concanavalin $A$ and its effect on tumor induction in potato. Physiol. Plant Pathol. 20: 35-42

107. Rao, S. S., Lippincott, B. B., Lippincott, J. A. 1982. Agrobacterium adherence involves the pectin portion of the cell host wall and is sensitive to the degree of pectin methylation. Physiol. Plant. 56:374-80

108. Ross, E. M., Gilman, A. G. 1983. Biochemical properties of hormonesensitive adenylate cyclase. Ann. Rev. Biochem. 49:533-64

109. Schmidt, E. L. 1979. Initiation of plant root-microbe interactions. Ann. Rev. Microbiol. 33:355-76

110. Sequeira, L. 1978. Lectins and their role in host-pathogen specificity. Ann. Rev. Phytopathol. 16:453-81

111. Sequeira, L. 1983. Recognition and specificity between plants and pathogens. See Ref. 21, pp. 301-10

112. Sequeira, L., Gaard, G., DeZoeten, G. A. 1977. Interaction of bacteria and host cell walls: Its relation to mechanisms of induced resistance. Physiol. Plant Pathol. 10:43-50

113. Sequeira, L., Graham, T. L. 1977. Agglutination of avirulent strains of Pseudomonas solanacearum by potato lectin. Physiol. Plant Pathol. 11:43-54

114. Sidhu, G. S. 1975. Gene-for-gene relationships in plant parasitic systems. Sci. Prog. London 62:467-85

115. Skipp, R. A., Samborski, D. J. 1974. The effect of the Sr6 gene for host resistance on histological events during the development of stem rust in near- isogenic wheat lines. Can. J. Bot. 52: 107-115

116. Stephen, J., Pietrowski, R. A. 1981. Bacterial Toxins. London: Van Nostrand Reinhold. 104 pp.

117. Strobel, G. A. 1973. The helminthosporoside-binding protein of sugarcane. Its properties and relationship to susceptibility to the eyespot disease. J. Biol. Chem. 248:1321-28

118. Suzuki, Y., Danko, S. J., Daly, J. M., Kono, Y., Knoche, H. W., Takeuchi, S. 1983. Comparison of activities of the host-specific toxin of Helminthosporium maydis, Race $T$, and a synthetic $C_{41}$ analog. Plant Physiol. 73:440-44

119. Suzuki, Y., Tegtmeier, K. J., Daly, J. M., Knoche, H. W. 1982. Analogs of host-specific phytotoxin produced by Helminthosporium maydis, race T. II. Biological activities. Bioorg. Chem. 11:313-21

120. Tegtmeier, K. J., Daly, J. M., Yoder, O. C. 1982. T-toxin production by nearisogenic isolates of Cochliobolus heterostrophus races $\mathrm{T}$ and $\mathrm{O}$. Phytopathology 72: 1492-95

121. Ueno; T., Nakashima, T., Fukami, H. 1982. Chemical basis of host recognition by Alternania species. See Ref. 6, pp. 235-54

122. Umehara, K., Nakahara, K., Kiyoto, S., Iwani, M.; Okamoto, M., et al. 1983. Studies on WF-3161, a new antitumor antibiotic. J. Antibiot. 36:478-83

123. Uritani, I., Kojima, M. 1979. Spore agglutinating factor and germ tube growth inhibiting factor in host plant. See Ref. 13, pp. 181-91

124. Vance, C. P. 1983. Rhizobium infection and nodulation: A beneficial plant disease? Ann. Rev. Microbiol. 37:399-424

125. Van Etten, H. 1979. Relationship between isoflavanoid phytoalexins and pathogenicity. See Ref. 13, pp. 301-16

126. Deleted in proof

127. Vams, J., Kuć, J. 1972. Suppression of the resistance response as an active mechanism for susceptibility in potatoPhytophthora interaction. In Phytotoxins in Plant Diseases, ed. R. K. S. Wood, A. Ballio, A. Graniti, pp. 465-68. London: Academic

128. Wade, M., Albersheim, P. 1979. Racespecific molecules that protect soybeans from Phytophthora megasperma var. sojae. Proc. Natl. Acad. Sci. USA 76: 4433-37

129. Wagoner, W., Loschke, D. C., Hadwiger, L. A. 1982. Two dimensional electrophoretic analysis of in vivo and in vitro synthesis of proteins in peas inoculated 
with compatible and incompatible Fusarium solani. Physiol. Plant Pathol. 20: 99-107

130. Walton, J. D., Earle, E. D. 1983. The epoxide in HC-toxin is required for activity against susceptible maize. Physiol. Plant Pathol. 22:371-76

131. Walton, J. D., Earle, E. D., Gibson, B. W. 1982. Purification and structure of the host specific toxin from Helminthosporium carbonum race 1. Biochem. Biophys. Res. Commun. 107:785-94

132. Ward, E. W. B., Buzzell, R. I. 1983. Influence of light, temperature and wounding on the expression of soybean genes for resistance to Phytophthora megasperma f. sp. glycinea. Physiol. Plant Pathol. 23:401-9

133. Ward, E. W. B., Stoessl, A. 1976. On the question of "elicitors" or "inducers" in incompatible interactions between plants and fungal pathogens. Phytopathology 66:940-41

134. Whatley, M. H., Bodwin, J. S., Lippincott, B. B., Lippincott, J. A. 1976. Role for bacterial cell envelope in infection site attachment. Infect. Immun. 13:108083

135. Wheeler, H. 1969. In Symposium on Potential Crop Protection, pp. 9-13 Ithaca: Cornell Univ. Press

136. Wheeler, H. 1981. Role in pathogenesis. See Ref. 36, pp. 477-94
137. Wolpert, T. J., Dunkle, L. D. 1983. Alterations in gene expression in sorghum induced by the host-specific toxin from Periconia circinata. Proc. Natl. Acad. Sci. USA 80:6576-80

138. Yoder, O. C., Scheffer, R. P. 1969. Role of toxin in early interactions of Helminthosporium victoriae with susceptible and resistant oats. Phytopathology 59:1954-59

139. Young, D. H., Kauss, H. 1983. Release of calcium from suspension-cultured Glycine max cells by chitosan, other polycations, and polyamines in relation to effects on membrane permeability. Plant Physiol. 73:698-701

140. Young, D. H., Kohle, H., Kauss, H. 1982. Effect of chitosan on membrane permeability of suspension-cultured $\mathrm{Gly}$ cine max and Phaseolus vulgaris cells. Plant Physiol. 70:1449-54

141. Ziegler, E., Albersheim, P. 1977. Host pathogen interactions. XIII: Extracellular invertases secreted by three races of a plant pathogen are glycoproteins which possess different carbohydrate structures. Plant Physiol. 59:1104-10

142. Ziegler, E., Pontzen, R. 1982. Specific inhibition of glucan-elicited glyceollin accumulation in soybeans by an extracellular mannan-glycoprotein of $P h y$ tophthora megasperma f. sp. glycinea. Physiol. Plant Pathol. 20:321-31 